\title{
Production of Pre-Basic Potato Seed by Polyvinyl Chloride - PVC - Articulate Gutters Hydroponic System
}

\author{
Jonny Everson Scherwinski-Pereira ${ }^{1 *}$, Carlos Alberto Barbosa Medeiros ${ }^{2}$, Gerson Renan \\ de Luces Fortes ${ }^{2}$ and Arione da Silva Pereira ${ }^{2}$ \\ ${ }^{l}$ Embrapa Recursos Genéticos e Biotecnologia; Núcleo de Biotecnologia; Laboratório de Cultura de Tecidos II; Av. \\ W5 Norte (final); C. P.: 02372; 70770-900; Brasília - DF - Brasil. ${ }^{2}$ Embrapa Clima Temperado; C. P.: 403; 96001 - \\ 970; Pelotas - RS - Brasil
}

\begin{abstract}
The development of more efficient and productive systems for pre-basic seed potato production would improve the quality of the propagative material used by the potato growers, directly affecting the crop yields. A two-year experiment was carried out to evaluate the potato pre-basic seed production by two types of hydroponic systems (fibrocement tiles and articulated PVC gutters), two cultivars ('Baronesa`and 'Eliza') and two types of propagative material (plants coming from in vitro culture and minitubers). The PVC gutters system was highly efficient. When using minitubers, this system reached multiplication rates up to 74 tubers per plant. Minitubers were more productive than in vitro plants, independent of cultivar and hydroponic system utilized.
\end{abstract}

Key words: Solanum tuberosum, soilless culture, multiplication, propagation, minitubers, micropropagation

\section{INTRODUCTION}

Although in recent years the technical management of the potato crop has improved, many producing areas still produce low yields, mainly due to the use of poor quality potato seed. The difficulty lies in the fact that tubers naturally tend to accumulate and transmit viral, bacteriological and fungal diseases to the next vegetative generation, which progressively reduces the yield potential. Moreover, growers have difficulty getting sufficient seed tubers of desired cultivars to plant crops in different seasons of the year (Assis, 1999; Rolot and Seutin, 1999; Pereira and Fortes, 2004).

Conventional methods for producing basic and certified potato seeds begins with the production of pre-basic material. Plants are produced in vitro using meristem culture and after an acclimatization period in greenhouse, are transferred to glasshouse where tubers are produced. The health risk at this stage depends in part upon the growth substrate used. Soil desinfestation generally is done with chemicals such as methyl bromide, which eliminates both pathogenic and beneficial microorganisms. This technique usually results in low yield of minitubers per plant, generally five or less, and is a serious constraint to the production (Daniels et al., 2000; Pereira, 2002; Fortes and Pereira, 2003).

The development of more efficient and productive systems with lower environmental impact would improve the quality of the propagative material used by the potato growers, directly affect the crop yields and reduce the production costs (Pereira and Fortes, 2003; Pereira and Fortes, 2004). The use of

\footnotetext{
* Author for correspondence: jonny@ cenargen.embrapa.br
} 
hydroponic systems offers an excellent alternative to reduce the potential risks of root and tuber contamination by the soil pathogens and also for eliminating the need of chemical disinfectants, generally very harmful to the human health and environment (Medeiros et al., 2001; Pereira and Fortes, 2003).

The aim of this study was to evaluate the efficiency of hydroponic systems for pre-basic seed potato production, taking into account the origin of propagative material used (minitubers and plants from in vitro culture).

\section{MATERIAL AND METHODS}

The experiments were carried out at the Embrapa Temperate Climate, Brazil, during two growing seasons: spring-summer (August to November 2000) and autumn-winter (March to July 2001). In both the experiments, the combinations of two hydroponic systems (fibrocement tiles and Polyvinyl Chloride - PVC - articulate gutters), two potato cultivars (Baronesa and Eliza) and two types of plant material (plants from in vitro culture and minitubers) were assessed. The experimental design was a randomized complete block, in a factorial $2 \times 2 \times 2$ design, with four replicates. The experimental unit had nine plants on the system of fibrocement tiles and six plants on the system of PVC gutters.

\section{Hydroponic systems}

Platforms of fibrocement tiles: Fibrocement tiles $(1.22 \times 1.10 \mathrm{~m})$, with $6 \mathrm{~cm}$ deep and $18 \mathrm{~cm}$ spaced channels, were covered with black polyethylene film $(100 \mu \mathrm{m}$ thick) and seated on wood structures with approximately $4 \%$ slope. For plant anchorage, the tile channels were partially filled out with a layer of medium size fragmented granite enough to block the sun light (to avoid it reaching the root system and stolons of the plants). In the Autumn-Winter experiment, besides the layer of fragmented granite, a film of black polyethylene $(100 \mu \mathrm{m}$ thick) was put covering it, as a complementary measure to avoid light penetration in the root system of the plants being developed. Small cuts in cross were made on the film to make it possible the planting and subsequent emergency of the sprouts and development of the stems. In this system, the plants were harvested at the end of the crop cycle.

\section{PVC articulate gutters}

This system was formed by two PVC gutters on wood supports with $4 \%$ slope. The upper gutter, fastened and positioned to support the shoot growth of the plants, had twelve holes with $20 \mathrm{~mm}$ diameter and $25 \mathrm{~cm}$ spaced. The lower gutter, in which the nutrient solution was circulated and where the roots and tubers grew, was moved away to expose the formed tubers, as soon as they reached diameter of about 2 to $3 \mathrm{~cm}$.

To minimize the light penetration in the root system of the plants, a polyethylene film was placed externally, along the junction of the two gutters. In the second experiment, as a complementary measure, a black polyethylene film of about $20 \mathrm{~cm}$ wide, was put on the borders of the upper gutter.

In this system, the plants and minitubers were positioned in the lower gutter, exactly under the holes of the upper gutter for the normal development of the aerial parts of the plants during their growth.

The space between the plants and minitubers for both hydroponic systems was $0.20 \mathrm{~m}$. The materials were displayed on small plates of phenolic foam $(2.5 \times 2.5 \times 3.8 \mathrm{~cm})$. The nutrient solution was supplied by the individual reservoirs at a flow rate of approximately $2 \mathrm{~L} \cdot \mathrm{min}^{-1}$. The irrigation intervals of the nutrient solution were 15 min with intervals of equal period from 6:00 am to 21:00 pm and $30 \mathrm{~min}$ from 21:00 pm to 6:00 am. The total capacity of the reservoir was adapted to provide approximately 21 of solution per plant.

The $\mathrm{pH}$ and the conductivity of the nutrient solution were monitored daily. During the experiments, the $\mathrm{pH}$ varied from 5.2 to 6.2 with no adjustment. Twice a week, the nutrient solution in the reservoir was replenished with macro and micronutrients.

\section{Vegetative material}

In vitro plants: In vitro plants of cultivars Baronesa and Eliza, of 5 to $7 \mathrm{~cm}$ high were washed, put immediately in the cubes of phenolic foam $(2.5 \times 2.5 \times 3.8 \mathrm{~cm})$ and transferred to the hydroponic systems.

Minitubers: Pre-basic minitubers classified as type III (Brasil, 1988), previously stored for six months at $4^{\circ} \mathrm{C}$, were used.

The hydroponic systems were tested in two growing seasons: Spring-summer and autumnwinter. The spring-summer experiment was 
carried out in a greenhouse. In the PVC gutters system, six harvests were done at a week interval, beginning 60 days after the planting. By the last harvest in the PVC gutter system (96 days), the fibrocement tile system was also harvested. A modified Clark's nutrient solution (1982), composed by (in mg.L $\mathrm{L}^{-1}$ ): $321 \mathrm{~N}-\mathrm{NO}_{3} ; 39 \mathrm{~N}^{-\mathrm{NH}_{4}}$; $12 \mathrm{P} ; 283 \mathrm{~K} ; 302 \mathrm{Ca} ; 37.8 \mathrm{Mg} ; 58.5 \mathrm{~S} ; 2.76 \mathrm{Fe}$; $0.97 \mathrm{Mn} ; 0.07 \mathrm{Cu} ; 0.30 \mathrm{Zn} ; 0.53 \mathrm{~B} 0$ and $15 \mathrm{Mo}$, was used

The autumn-winter experiment was carried out in a plastic greenhouse. In the PVC gutter system, nine harvests were made at weekly intervals; the first one was 49 days after planting. The final harvest of PVC gutter system and the unique harvest of the fibrocement system were done 107 days after the planting. Differently from the first experiment, the nutrients were supplied using the commercial solution Kristalon Laranja ${ }^{\circledR} *$ ( 0.8 g.L ${ }^{1}$ ), containing micronutrients (Tense-cocktail ${ }^{\circledR}$, 0.03 g. $\mathrm{L}^{-1}$ ) and calcium nitrate (Hydro®, 0.8 g.L $\left.{ }^{1}\right)$. The nutrient solution was composed as follow (in mg.L $\mathrm{L}^{-1}$ ): $160 \mathrm{~N}-\mathrm{NO}_{3} ; 20 \mathrm{~N}-\mathrm{NH}_{4} ; 41.9 \mathrm{P} ; 239.1$ $\mathrm{K} ; 152.8 \mathrm{Ca} ; 14.5 \mathrm{Mg} ; 64 \mathrm{~S} ; 1.71 \mathrm{Fe} ; 1.1 \mathrm{Mn} ; 0.19$ $\mathrm{Cu} ; 0.36 \mathrm{Zn} ; 0.36 \mathrm{~B}$ and $0.07 \mathrm{Mo}$.

In both the experiments, the number, weight and size of the pre-basic tubers were evaluated. Data were submitted to the analysis of variance (ANOVA). Means were compared through the Duncan's test. Significance level was established at $5 \%$.

\section{RESULTS AND DISCUSSION}

In the spring-summer season, tuber yield in the PVC gutter system reached 34.5 tubers per plant, on average, while in the tile system, the yield was 13.5 tubers. In the PVC gutter system, the cultivar Baronesa, using minitubers and plants produced 49.6 and 32.4 tubers, respectively (Table 1 ). For cultivar Eliza, the productivity in the PVC gutter system was also high, with 32.9 and 23.0 tubers per plant, when minitubers and plants were used, respectively. On average, minitubers provided the largest multiplication rate. However, when the systems were individually evaluated, the differences were significant only for Baronesa in relation to the type of propagative material used. As might be expected significant differences in the multiplication rates were attributable to the cultivar. On average, Baronesa presented a yield of
28.5 tubers per plant, which was higher than the 19.5 tubers obtained for Eliza.

In the autumn-winter season, the number of tubers formed in the PVC gutters system was higher than in the tiles fibrocement. For Eliza, using tubers and plants, the PVC gutter system resulted in 43.6 and 29.0 tubers per plant, respectively, which was significantly higher than that obtained in the fibrocement tile system. In the PVC gutter system, Baronesa propagated by minitubers yielded 74.7 tubers per plant.

The difference in yield between the hydroponic systems was due to the fact that in the PVC gutter system, harvests took place as soon as the tubers reached a diameter of $2-3 \mathrm{~cm}$. The harvest in scale provided by the PVC gutter system constituted the big differential in relation to the fibrocement tile system. Besides, the harvest of small tubers stimulated the differentiation and the formation of new ones. Thus, the energy to be used for increasing the tuber size was for the formation of new tubers, allowing high multiplication rates (Medeiros et al., 2002). This did not happen in the tile system, where the full development of tubers limited the availability of photosynthates for new tuber formation. For that reason, it was expected that the multiplication rate per plant would be significantly higher in the PVC gutter system when compared to the fibrocement tile system, in which the harvest took place only in the end of the crop cycle with the formation of larger tubers and, consequently, smaller numbers.

In the PVC gutter system, the potato plants of Baronesa formed by material derived from the tissue culture had symptoms of deficient growth, reducing the production of the tubers (Table 1). Although this could not be explained, some hypotheses, like deficiency of some nutrient in the solution as $\mathrm{P}$ and $\mathrm{Ca}$, or even the virus presence in the material, could be made. However, it was unlikely that these symptoms appeared as a result of the deficiency of some elements in the solution, because it was an isolated phenomenon observed only in the PVC gutter system for Baronesa when the plants from in vitro culture were used. The material was tested, for the presence of virus, with negative results. Necroses in the extremity of the aerial parts of the plants were also observed when this material was used in the PVC gutter system in the experiment during Spring-Summer. However, these symptoms showed no influence on the yield of the plants. As with the Autumn-Winter experiment, it was not possible to detect it cause. 
These have been reports describing the occurrence of physiological problems in tubers or other organs produced under hydroponic systems (Valmorbida and Boaro, 2007). Wheeler et al. (1990) mentioned damages in the periderm followed by superficial darkening of the tubers. The authors suggested that this problem would result from the reaction of the tuber to the nutrient solution, in a phenomenon known as "salt burn". Rolot and Seutin (1999) observed that some cultivars formed transluced areas attributable to a lack of starch accumulation in the insert point of the tuber with the stolon. In this study, tubers reaction to solution were not observed. However, some tubers produced in the fibrocement tile system showed similar problems to those described by Rolot and Seutin (1999). There could be a relationship with the harvest time, because it was only observed in the older tubers, with a darkening followed by a breakdown of tissues in the insert point, suggesting longer time of the material under high humidity conditions.

In general, higher yields were produced when minitubers were used as propagules, except for Eliza in the fibrocement tile system in the autumn- winter experiment (Table 1). It was clear that the most vigorous development of the plants originated from this material showed that the tuber-seed reserves influenced the initial development of the plants. Furthermore, each minituber originated two to three stems. This determined the formation of large number of stolons per plant, affecting the productivity in the two hydroponic systems. The plants demonstrated a slower growth, developing just one stem, which partially explained the larger number of tubers obtained per plant when minitubers were used.

The tuber weight at harvest in the fibrocement tile system were significantly higher than those produced in the PVC gutter system. Significant differences for tuber weight were not observed between in vitro plants and minitubers, and between the cultivars, in the spring-summer experiment. However, the use of minitubers resulted in the tubers with higher weight than those plants in the autumn-winter experiment. However, considering the systems, the differences were significant only for the fibrocement tile system (Table 2).

Table 1 - Number of tubers produced by potato plants cultivated in two hydroponic systems with two types of propagative material and two cultivars in the Spring-Summer and Autumn-Winter growing seasons.

\begin{tabular}{|c|c|c|c|c|c|}
\hline \multicolumn{6}{|c|}{ Spring-Summer growing seasons } \\
\hline \multirow[b]{2}{*}{ SYSTEM } & \multicolumn{2}{|c|}{ Cv. Baronesa } & \multicolumn{2}{|c|}{ Cv. Eliza } & \multirow[b]{2}{*}{ Average } \\
\hline & Minitubers & Plantlets & Minitubers & Plantlets & \\
\hline PVC gutters & $49.6 \mathrm{aA}$ & $32.4 \mathrm{aB}$ & $32.9 \mathrm{aA}$ & $23.0 \mathrm{aA}$ & $34.5 \mathrm{a}$ \\
\hline Fibrocement tiles & $21.0 \mathrm{bA}$ & $11.0 \mathrm{bB}$ & $13.5 \mathrm{bA}$ & $8.6 \mathrm{bA}$ & $13.5 \mathrm{~b}$ \\
\hline Average & $35.3 \mathrm{~A}$ & $21.7 \mathrm{~B}$ & $23.2 \mathrm{~A}$ & $15.8 \mathrm{~B}$ & \\
\hline Average (cultivar) & \multicolumn{2}{|c|}{$28.5 \mathrm{~A}$} & \multicolumn{2}{|c|}{$19.5 \mathrm{~B}$} & \\
\hline \multicolumn{6}{|c|}{ Autumn-Winter growing seasons } \\
\hline & \multicolumn{2}{|c|}{ Cv. Baronesa } & \multicolumn{2}{|c|}{ Cv. Eliza } & \\
\hline SYSTEM & Minitubers & Plantlets & Minitubers & Plantlets & Average \\
\hline PVC gutters & $74.7 \mathrm{aA}$ & $2.7 \mathrm{aB}$ & $43.6 \mathrm{aA}$ & $29.0 \mathrm{aB}$ & $37.5 \mathrm{a}$ \\
\hline Fibrocement tiles & $11.6 \mathrm{bA}$ & $4.0 \mathrm{aB}$ & $8.7 \mathrm{bA}$ & $5.8 \mathrm{bA}$ & $7.5 \mathrm{~b}$ \\
\hline Average & $43.1 \mathrm{~A}$ & $3.3 \mathrm{~B}$ & $26.1 \mathrm{~A}$ & $17.4 \mathrm{~B}$ & \\
\hline Average (cultivar) & \multicolumn{2}{|c|}{$23.2 \mathrm{~A}$} & \multicolumn{2}{|c|}{$21.7 \mathrm{~A}$} & \\
\hline
\end{tabular}


Table 2 - Tuber weight (g) produced by potato plants cultivated in two hydroponic systems from two types of propagative material and two cultivars in the spring-summer and autumn-winter growing season.

\begin{tabular}{|c|c|c|c|c|c|}
\hline \multicolumn{6}{|c|}{ Spring-summer growing seasons } \\
\hline \multirow[b]{2}{*}{ SYSTEM } & \multicolumn{2}{|c|}{ Cv. Baronesa } & \multicolumn{2}{|c|}{ Cv. Eliza } & \multirow[b]{2}{*}{ Average } \\
\hline & Minitubers & Plantlets & Minitubers & Plantlets & \\
\hline PVC gutters & $12.9 \mathrm{aA}$ & $14.7 \mathrm{aA}$ & $15.3 \mathrm{aA}$ & $14.0 \mathrm{aA}$ & $14.3 \mathrm{a}$ \\
\hline Fibrocement tiles & $3.3 \mathrm{bA}$ & $3.9 \mathrm{bA}$ & $4.4 \mathrm{bA}$ & $5.0 \mathrm{bA}$ & $4.1 \mathrm{~b}$ \\
\hline Average & $8.1 \mathrm{~A}$ & $9.3 \mathrm{~A}$ & $9.9 \mathrm{~A}$ & $9.5 \mathrm{~A}$ & \\
\hline Average (cultivar) & \multicolumn{2}{|c|}{$8.7 \mathrm{~A}$} & \multicolumn{2}{|c|}{$9.7 \mathrm{~A}$} & \\
\hline \multicolumn{6}{|c|}{ Autumn-winter growing seasons } \\
\hline \multirow[b]{2}{*}{ SYSTEM } & \multicolumn{2}{|c|}{ Cv. Baronesa } & \multicolumn{2}{|c|}{ Cv. Eliza } & \multirow[b]{2}{*}{ Average } \\
\hline & Minitubers & Plantlets & Minitubers & Plantlets & \\
\hline PVC gutters & $24.1 \mathrm{aA}$ & $15.5 \mathrm{aB}$ & $44.8 \mathrm{aA}$ & $12.9 \mathrm{aB}$ & $24.3 \mathrm{a}$ \\
\hline Fibrocement tiles & $4.8 \mathrm{bA}$ & $4.7 \mathrm{bA}$ & $6.0 \mathrm{bA}$ & $3.9 \mathrm{bA}$ & $4.9 \mathrm{~b}$ \\
\hline Average & $14.4 \mathrm{~A}$ & $10.1 \mathrm{~B}$ & $25.4 \mathrm{~A}$ & $8.4 \mathrm{~B}$ & \\
\hline Average (cultivar) & \multicolumn{2}{|c|}{$12.3 \mathrm{~B}$} & \multicolumn{2}{|c|}{$16.9 \mathrm{~A}$} & \\
\hline
\end{tabular}

Means following by different letters, small letters in the vertical and capital letters in the horizontal within of each cultivar, differ for the Duncan test $(\mathrm{P} \leq 0.05 \%)$.

In general, it was observed that the cropping season influenced the number of harvests in the PVC gutter system (Fig. 1). The temperatures in the beginning of the growth were higher in the autumn-winter season than in the spring-summer season. As a result, a faster development of the plants and earlier start of tuber yield (49 days after planting) occurred. The crop cycle reached 107 days, allowing nine harvests and, possibly, the highest yield per plant in comparison with the previous experiment. During the spring-summer experiment lower temperatures were observed in the beginning of the growing period. This delayed the initial growth of plants and, consequently, the beginning of tuber yield, which took place 60 days after the planting. However, the crop cycle was shorter (96 days), possibly due to higher temperatures occurring in the beginning of tuber production.

The distribution of tubers among the size classes was more homogeneous in the fibrocement tile than in the PVC gutter system and, on average, about $60 \%$ of the tubers produced in this system were classified as big (Classification type I to III; Brasil, 1988) (Fig. 2). On the other hand, the higher control on the size of the tubers harvested in the PVC gutter system resulted most of the tubers $(60 \%$ to $70 \%)$ to the classes IV and V, which would made it a suitable system to minitubers production (Medeiros et al., 2002).

The results demonstrated that the use of hydroponic systems for the production of pre-basic potato seed could provide a significant increase in the multiplication rate of minitubers production compared to the conventional technique. The higher efficiency in the use of nutrients for the crop is, probably, the most important factor to determine higher yields. The hydroponic systems may eliminate some cultural practices needed in the conventional process, such as soil desinfestation with methyl bromide, reduce the potential risks of plant contamination by soil microorganisms and result in the production of propagative material of higher sanitary quality. 


\section{Spring-summer growing season}

A

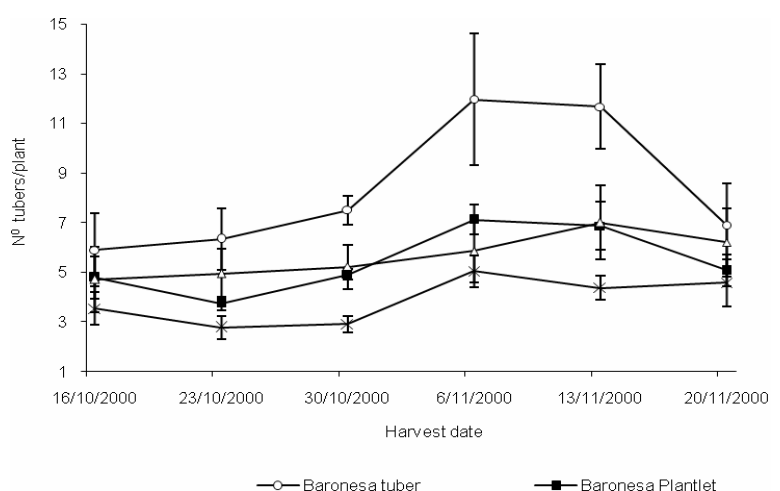

$\multimap$ Baronesa tuber

$\rightarrow$ - Baronesa Plantlet
$\mathrm{C}$

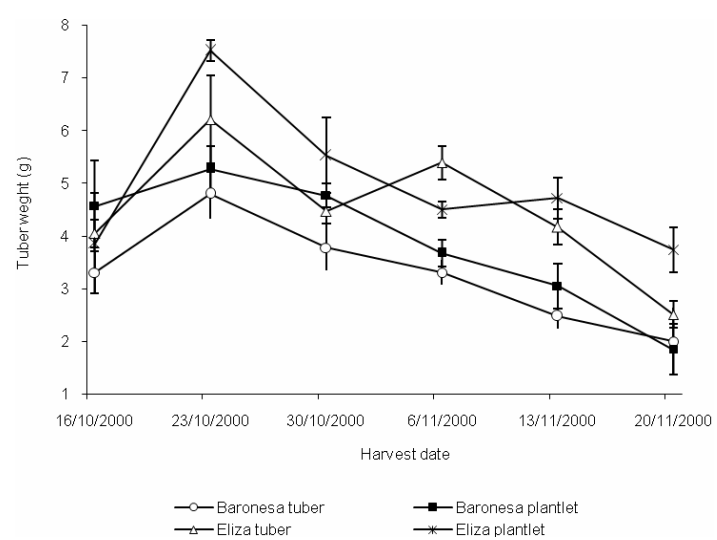

Autumn-winter growing season

B

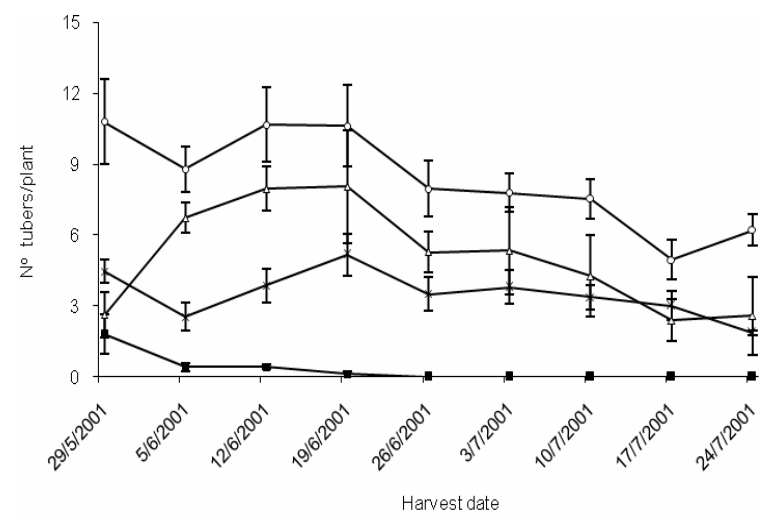

$\ldots$ Baronesa Tuber

$\stackrel{\sim \text { Baronesa T }}{\longleftarrow \text { FlizaT Tuber }}$

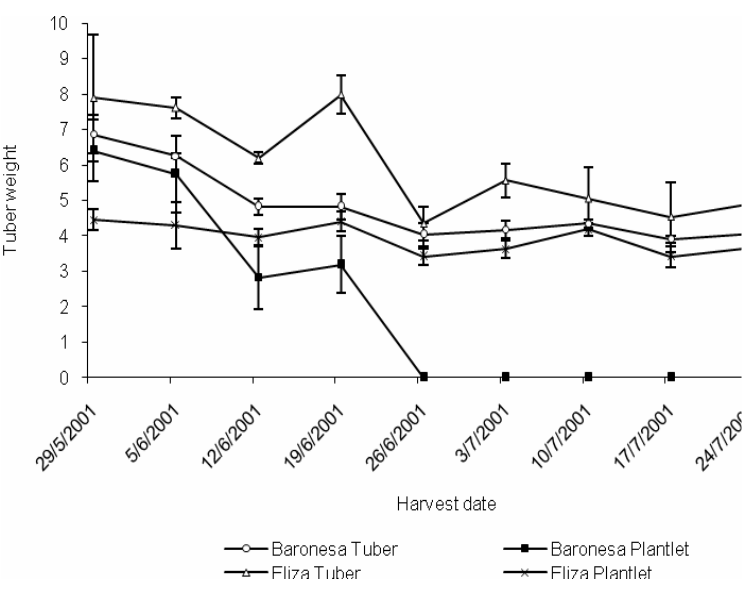

Figure 1 - Tuber number $(\mathrm{A}, \mathrm{B})$ and weight $(\mathrm{g})(\mathrm{C}, \mathrm{D})$ produced in the PVC gutter system as a function of harvest time and source of propagule during the spring-summer and autumn-winter growing season. Each point represents the mean of four replications and the vertical bars represent \pm standard error of the mean. 
Spring-summer growing season

A

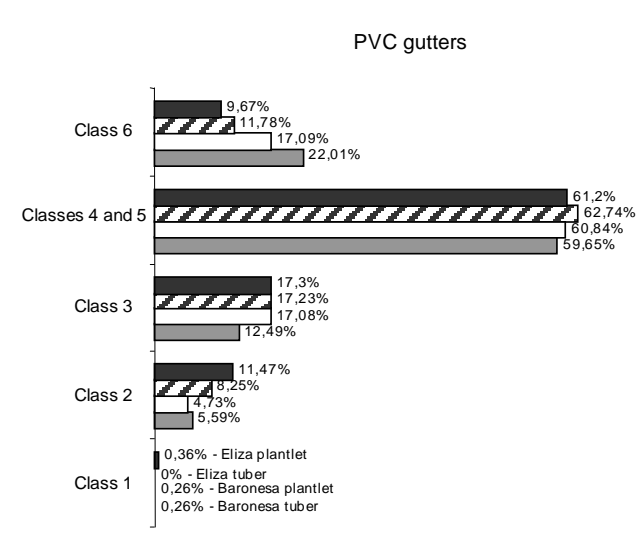

B

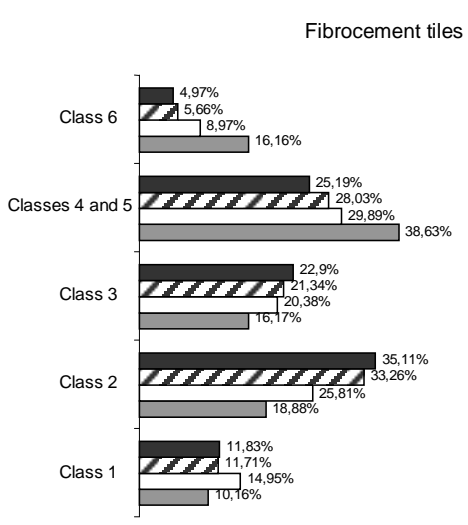

Autumn-winter growing season

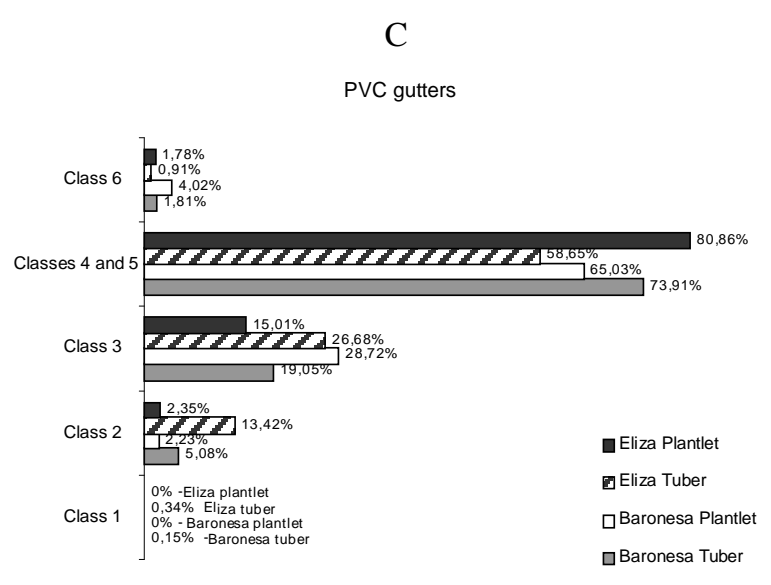

D

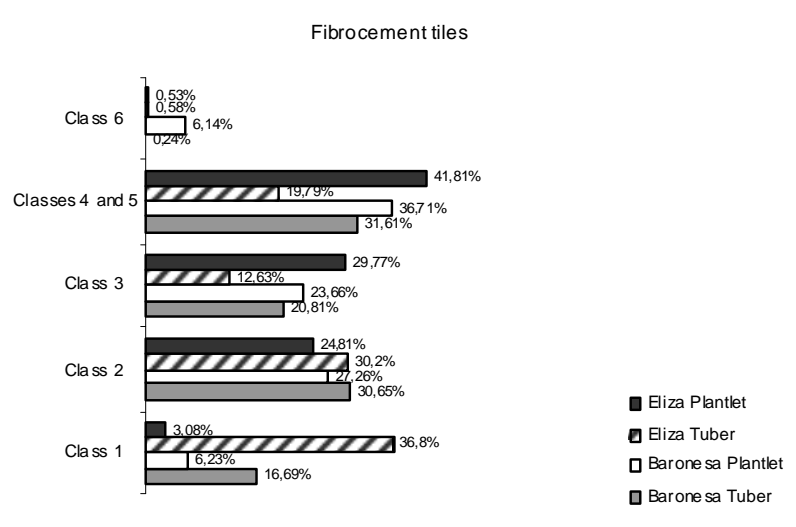

Figure 2 - Classes of tubers in percentage of the total harvested in the PVC gutters system (A, C) and fibrocement tiles $(\mathrm{B}, \mathrm{D})$ during the spring-summer and autumn-winter growing season.

\section{RESUMO}

Um experimento realizado por dois anos consecutivos avaliou a produção de sementes pré-básicas de batata por meio de sistemas de cultivo hidropônico. $\mathrm{O}$ trabalho testou a combinação de dois sistemas de cultivo (telha de fibrocimento e calhas de PVC articuladas), duas cultivares (Baronesa e Eliza) e dois tipos de material propagativo (plântulas oriundas do cultivo in vitro e minitubérculos). O sistema de calhas de PVC foi altamente eficiente. Quando foi utilizado minitubérculos, este sistema alcançou taxas de multiplicação de até 74 tubérculos por planta. De modo geral, o uso de minitubérculos como material propagativo apresentou os melhores resultados de produtividade quando comparada ao material in vitro, independentemente da cultivar e sistemas hidropônicos utilizados.

\section{REFERENCES}

Assis, M. (1999), Novas tecnologias na propagação de batata. Informe Agropecuário 20, 30-33.

Boersig, M.R. and Wagner, S.A. (1988), Hydroponic systems for production of seed tubers. Am. Potato J. 65, 470-471. 
Brasil (1988), Normas gerais para certificação de batata-semente. Brasília: Ministério da Agricultura, pp. 1-30.

Clark, R.B. (1982), Nutrient solution growth of sorghum and corn in mineral nutrition studies. $J$. Pl. Nutrit. 5, 1039-1057.

Daniels, J.; Medeiros, C.A.B. and Fortes, G.R.L. (2000), Sistema de produção de batata-semente. Pelotas: Embrapa Clima Temperado, pp.1-23.

David, P.P.; Trotman, A.A.; Mortlley, D.G.; Bonsi,C.K.; Loretan, P.A. and Hill, W.A. (1995) Foliage removal influences sweetpotato biomass yields in hydroponic culture. Hortsc. 30, 10001002.

Medeiros, C.A.B.; Pereira, A.S.; Daniels, J. and Pereira, J.E.S. (2001), Sistemas hidropônicos para produção de sementes pré-básicas de batata. In: Encontro Nacional de Produção $e$ Abastecimento de Batata e Seminário Nacional de Batata Semente, 11, Uberlândia: UFU, pp.1-4.

Medeiros, C.A.B.; Ziemer, A.H.; Daniels J. and Pereira, A.S. (2002), Produção de sementes prébásicas de batata em sistemas hidropônicos. Hort. Bras. 20, 110-114.

Murashige, T. and Skoog, F. (1962), A revised medium for rapid growth and bioassays with tobacco tissue cultures. Physiol. Plan. 15, 473497.
Pereira, J.E.S. and Fortes, G.R.L. (2004), Produção de mudas pré-básicas de batata por estaquia a partir de plantas micropropagadas. Hort. Bras. 22, 185-191.

Pereira, J.E.S. and Fortes, G.R.L. (2003), Protocolo para produção de material propagativo de batata em meio líquido. Pesq. Agr. Bras. 38, 1035-1043.

Rolot, J.L. and Seutin, H. (1999), Soilless production of potato minitubers using a hydroponic technique. Am. J. Pot. Res. 42, 457-469.

Rolot, J.L. ; Seutin, H. and Michelante, D. (2002), Production de minitubercules de pomme de terre par hydroponie: évaluation d'um système combinant lês techniques "NFT" et "Gravel Culture" pour deux types de solution nutritives. Biotechnol. Agron. Soc. Environ. 6, 155-161.

Valmorbida, J. and Boaro, C.S.F. (2007), Growth and development of Mentha piperita L. in nutrient solution as affected by rates of potassium. Braz. arch. biol. technol. 50, 379-384.

Wheeler, R.M.; Mackowiak, C.L.; Sager, J.C.; Knott, W.M. and Hinkle, C.R. (1990), Potato growth and yield using nutrient film technique (NFT). Am. J. Pot. Res. 67, 177-187.
Received: April 12, 2007; Revised: October 26, 2007 . Accepted: August 06, 2008. 